\title{
Immunoexpression of Vascular Endothelial Growth Factor, $\beta$ - cell Lymphoma 2 and Cluster of Differentiation 68 in Cerebellar Tissue of Rats Treated with Ganoderma lucidum
}

\author{
Inmunoexpresión del Factor de Crecimiento Endotelial Vascular, Linfoma de Células $\beta 2$ y \\ Grupo de Diferenciación 68 en Tejido Cerebeloso de Ratas Tratadas con Ganoderma lucidum
}

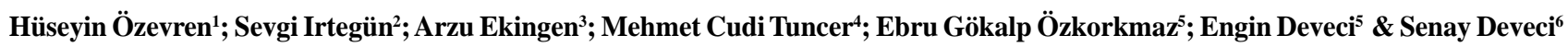

ÖZEVREN, H.; IRTEGÜN, S.; EKINGEN, A.; TUNCER, M. C.; GÖKALP ÖZKORKMAZ, E.; DEVECI, E. \& DEVECI, S. Immunoexpressions of Vascular endothelial growth factor, $\beta$-cell lymphoma 2 and Cluster of Differentiation 68 in cerebellar tissue of rats treated with Ganoderma lucidum. Int. J. Morphol., 36(4) :1453-1462, 2018.

SUMMARY: Traumatic brain injury (TBI) can potentially lead to hemorrhages in all areas of the skull, which can damage cells and nerve connections. This study aims to investigate the protective effects of Ganoderma lucidum polysaccharides (GLPS) as a antioxidant on cerebellar cell tissues after traumatic brain injury in rats. Sprague Dawley rats were subjected to TBI with a weight-drop device using 300 g$1 \mathrm{~m}$ weight-height impact. The groups are consisted of control, trauma, and trauma+Ganoderma lucidum groups. At seven days post-brain injury, experimental rats were decapitated after intraperitoneal administration of ketamine HCL ( $0.15 \mathrm{ml} / 100 \mathrm{~g}$ body weight). Cereballar samples were taken for histological examination or determination of malondialdehyde (MDA) and glutathione (GSH) levels and myeloperoxidase (MPO) activity. Significant improvement was observed in cells and vascular structures of Ganoderma lucidum treated groups when compared to untreated groups. It is believed that Ganoderma lucidum may have an effect on the progression of traumatic brain injury. Ganoderma lucidum application may affect angiogenetic development in blood vessel endothelial cells, decrease inflammatory cell accumulation by affecting cytokine mechanism and may create apoptotic nerve cells and neuroprotective mechanism in glial cells.

KEY WORDS: VEGF; ßcl-2; CD68, Ganoderma lucidum; Traumatic brain injury; Cerebellum; Histopathology; Rat.

\section{INTRODUCTION}

Traumatic brain injury is an important cause of death, memory loss and physical disability. After trauma, nerve fiber damage and cell loss occur. Direct cerebellar injury is much less common than supratentorial trauma (Tsai et al., 1980). Some of the classically identified consequences of direct traumatic injury to the cerebellum are hypotonia, ataxia, dysmetria, tremor, dysdiadochokinesis, and vertigo (Potts et al., 2009). Cells from various brain regions respond differently to mechanical injury and Purkinje neurons are most affected by cerebellar trauma (Slemmer et al., 2004).

Ganoderma lucidum is a medicinal mushroom and used in traditional Chinese medicine, with a very broad spectrum of biological activities and pharmacological functions (Potts et al.). Ganoderma lucidum, called
"Lingzhi" in Chinese and "Reishi" in Japanese, is one of the most commonly used mushrooms by traditional Chinese medicine in Asia (Paterson et al., 2006). Ancient Chinese medical scholars suggested that G. lucidum could strengthen body resistance and consolidate the constitution of patients, ie, "Fuzheng Guben", which is one of the major principles in the therapeutics of traditional Chinese medicine (Cong \& Lin, 1981). Nerve growth factor has potent biological activities such as promoting neuronal survival and neuritogenesis (D'Ambrosi et al., 2000). It is targeted as a potential therapeutic drug for the treatment of neurodegenerative disorders (Hefti \& Weiner, 1986; Connor \& Dragunow, 1998). However, nerve growth factor is unstable and is unable to cross blood-brain barrier because of its high molecular polypeptide (Granholm et al., 1998).

${ }^{1}$ Department of Neurosurgery, Faculty of Medicine, University of Dicle, Diyarbakir, Turkey.

${ }^{2}$ Department of Medical Biology, Faculty of Medicine, University of Dicle, Diyarbakir, Turkey.

${ }^{3}$ Vocational School of Health Services, University of Batman, Batman, Turkey.

${ }^{4}$ Department of Anatomy, Faculty of Medicine, University of Dicle, Diyarbakir, Turkey.

${ }^{5}$ Department of Histology and Embryology, Faculty of Medicine, University of Dicle, Diyarbakir, Turkey.

${ }^{6}$ Atatürk Health High School, University of Dicle, Diyarbakir, Turkey. 
ÖZEVREN, H.; IRTEGÜN, S.; EKINGEN, A.; TUNCER, M. C.; GÖKALP ÖZKORKMAZ, E.; DEVECI, E. \& DEVECI, S. Immunoexpressions of Vascular endothelial growth factor, $\beta$-cell lymphoma 2 and Cluster of Differentiation 68 in cerebellar tissue of rats treated with Ganoderma lucidum. Int. J. Morphol., 36(4) :1453-1462, 2018.

Hence, the potential medicinal values of culinary and medicinal mushrooms have attracted intense interest in the search for pharmacological compounds that mimic the nerve growth factor activity in the prevention of neurodegenerative diseases.

G. lucidum is reportedly known to have anticancer, antitumor, antidiabetic, and anti-inflammatory effects (Harhaji Trajkovic' et al., 2009; Weng et al., 2009; Huang et al., 2010). Oral administration of Ganoderma lucidum has been shown to significantly reduce both cerebral infarct area and neuronal apoptosis in the ischemic cortex (Zhou et al., 2012). Recent studies have demonstrated the neuroprotective effect of Ganoderma lucidum to reduce oxidative stress invitro (Zhao et al., 2005) to induce neuronal differentiation (Cheung et al., 2000) and to prevent the harmful effects of the exterminating toxin Ab in Alzheimer's disease in cultured rat neurons (Lai et al., 2008). Moreover, neuroprotective effects of $G$. lucidum have been demonstrated. Polysaccharides from G. lucidum protected rat cerebral cortical neurons from injury induced by hypoxia/ reoxygenation ex-posure (Zhao et al., 2004) as well as reduced neurological deficits in rats after cerebral ischemic injury (Zhou et al., 2010). Furthermore, G. lucidum extract protected dopaminergic neurons from degeneration (Zhang et al., 2011). Altogether, G. lucidum has been postulated as a novel therapeutic approach in the prevention and treatment of neurodegenerative diseases such as stroke (Zhao et al., 2004; Zhou et al., 2010) Parkinson disease (Zhang et al., 2011) or Alzheimer disease (Zhou et al., 2010).

VEGF-induced blood vessel growth is essential for nervous tissue growth during embryonic development. This is demonstrated by the observation that loss of VEGF expression by central nervous system (CNS) neurons impairs vascularisation, curbs neuronal expansion and results in neuronal apoptosis in the developing brain (Haigh et al., 2003; Raab et al., 2004). The blood-brain barrier is a dynamically regulated physical barrier between the central nervous system and circulation consisting of endothelial cells that line cerebral microvessels. While the BBB sustains the unique chemical microenvironment critical for neuronal activity in the central nervous system, it also restricts access to therapeutic drugs. VEGF increases permeability of bloodbrain barrier (BBB) by induction of synthesis and secretion of nitric oxide (NO) and activity of cGMP (Nag et al., 1997). Bcl-2 is an integral membrane protein that functions primarily as an inhibitor of apoptosis. Overexpression of Bcl-2 in both neuronal and hematopoietic cell lines is protective following growth factor withdrawal (Garcia et al., 1992; Allsopp et al., 1993; Batistatou et al., 1993). In vivo overexpression of BCL-2 during embryogenesis or postnatally can significantly reduce the extent of naturally occurring cell death as well as rescue many neurons from external injuries (e.g. axotomy or ischemia) or genetic lesions (Dubois-Dauphin et al., 1994; Farlie et al., 1995; Chen et al., 1996; de Bilbao \& Dubois-Dauphin, 1996). Using a model of combined traumatic brain injury and hypoxemia, Clark et al. (1997) observed an up-regulation of Bcl-2 in cortical and hippocampal neurons that survived the traumatic injury. On the other hand, CD 68-positive microglial cells have frequently been observed in human fetal white matter (Andjelkovic et al., 1998; Rakic \& Zecevic, 2003). In the aged rat brain there is an increase in CD68 + cells throughout the parenchyma in both grey and white matter and appearance of MHCII positive aggregates of cells in and adjacent to white matter (Perry et al., 1993). Similar changes have been observed in aged mice. These changes have been associated with an increased sensitivity to systemic inflammatory challenge with increased cytokine production and altered behavioural responses (Barrientos et al., 2006; Chen et al., 2008; Henry et al., 2009; Wynne et al., 2010).

The purpose of this study was to evaluate immunoexpressions of vascular endothelial growth factor, Bcl-2, CD68 and Western blot analysis in cerebellar tissues treated with Ganoderma lucidum after traumatic brain injury in rats.

\section{MATERIAL AND METHOD}

Animals and experimental design. The investigation was conducted in accordance with the Guide for the Care and Use of Laboratory Animals published by US National Institutes of Health (NIH Publication no. 85-23, revised 1996). All procedures performed in this experiment were approved by the Ethics Committee for the Treatment of Experimental Animals (Faculty of Medicine, University of Dicle, Turkey, Protocol Number: 2016/15). Male SpragueDawley rats $(280-330 \mathrm{~g})$ were maintained under $23 \pm 2^{\circ} \mathrm{C}$ and $12 \mathrm{~h}$ light/dark cycles with ad libitum access to standard pelleted food and water. A rectal probe was inserted, and the animals were positioned on a heating pad that maintained the body temperature at $37^{\circ} \mathrm{C}$. The widely used diffuse brain injury model described by Marmarou et al. (1994). Briefly, a trauma device which works by dropping a constant weight from a specific height through a tube was used. A weight of $300 \mathrm{~g}$ was dropped from a $1 \mathrm{~m}$ height, which can induce mild trauma, as shown by Ucar et al. (2006). The rats were divided into 3 groups as control, trauma and trauma+Ganoderma lucidum groups $(20 \mathrm{ml} / \mathrm{kg}$ per day via gastric gavage). Thirty minutes after the trauma, rats were injected Ganoderma lucidum polysaccharides via gastric gavage for seven days in trauma+Ganoderma lucidum group $(n=12)$. The rats of control $(n=12)$ and trauma groups $(n=12)$ were only administered $1.5 \mathrm{ml}$ physiologic saline solution subcutaneously for 7 days. All rats at the end of experiment 
were no difference in food/water consumption and body weight gain between experimental and control rats were observed. After seven days, all animals were sacrificed by an intraperitoneal injection of $5 \mathrm{mg} / \mathrm{kg}$ xylazine $\mathrm{HCl}$ (Rompun, Bayer HealthCare AG, Germany) and $40 \mathrm{mg} / \mathrm{kg}$ ketamine $\mathrm{HCl}$ (Ketalar, Pfizer Inc, USA). Each group had 12 animals. All of them were utilized for biochemical parameters and the assessment of histological examination in each group.

Histological investigations. Tissue samples were homogenized with ice-cold $150 \mathrm{mM} \mathrm{KCl}$ for the determination of malondialdehyde and glutathione levels. The MDA levels were assayed for products of lipid peroxidation, and the results were expressed as nmol MDA/ $\mathrm{g}$ tissue (Sohrab et al., 2015). GSH level was determined by the spectrophotometric method, which was based on the use of Ellman's reagent, and the results were expressed as mmol glutathione/g tissue (Preston \& Phillips, 2016). Myeloperoxidase activity in tissues was measured by a procedure similar to that described by Hillegass et al. (1990). Myeloperoxidase activity was expressed as U/g tissue. To evaluate the blood-brain barrier (BBB) integrity, Evans blue (EB) dye was used as a marker of albumin extravasation (Hakan et al., 2010). EB was expressed as $\mathrm{mg} / \mathrm{mg}$ of cerebellar tissue against a standard curve. Cerebellar edema was evaluated by the drying-weighing method based on the measurement of the water content of the brain (Gumerlock et al., 1996). The percentage of water was calculated according to the following formula: $\% \mathrm{H} 2 \mathrm{O}=[$ (wet weightdry weight)/wet weight] X 100. At the end of the experiment, all animals were anesthetized via the intraperitoneal administration of ketamine HCL $(0.15 \mathrm{ml} / 100 \mathrm{~g}$ body weight). The cerebellum were dissected. For the histological examination, cerebellum tissues were fixed in $10 \%$ formaldehyde solution, post fixed in $70 \%$ alcohol, and embedded in paraffin wax. The sections were stained with $\mathrm{H} \& \mathrm{E}$ for histopathological examinations.

Immunohistochemical technique. Sections were brought to distilled water and washed in 3 x 5 min Phosphate Buffered Saline (PBS). Catalog number 10010023, Thermo Fischer Scientific Fremont, CA, USA. Antigen retrieval was done in microwave (Bosch $\AA, 700$ watt) for $3 \mathrm{~min} x 90^{\circ} \mathrm{C}$. They were subjected to a heating process in a microwave oven at 700 watts in a citrate buffer ( $\mathrm{pH} \mathrm{6)}$ solution for proteolysis. Sections were washed in $3 \times 5$ min PBS and incubated with hydrogen peroxide [K-40677109,64271 Hydrogen peroxide $\left(\mathrm{H}_{2} \mathrm{O}_{2}\right)$ Dortmund+Germany, MERCK] (3 ml \% 30 Hydrogen peroxide $\left(\mathrm{H}_{2} \mathrm{O}_{2}\right)+27 \mathrm{ml}$ methanol) for $20 \mathrm{~min}$. Sections were washed in $3 \times 5$ min PBS min and blocked with Ultra V Block (lot: PHL150128, Thermo Fischer, Fremont, CA, USA) for $8 \mathrm{~min}$. After draining, primary antibodies were directly applied to sections distinctly (Vascular Endothelial Growht Factor (VEGF), 1:100, lot\#MA5-12184, Thermo Fischer, Fremont, CA, USA; B cell lymphoma-2, 1:100, lot\#MA5-11757, Thermo Fischer, Fremont, CA, USA; Bax, 1:100, lot\#MA5-12184, Thermo Fischer, Fremont, CA, USA; Cluster of Differentiation 68 (CD68), 1:100, lot\#MA5-13324, Thermo Fischer, Fremont, CA, USA) for $14 \mathrm{~min}$. After washing with PBS, Streptavidin Peroxidase (lot: PHL150128, Thermo Fischer, Fremont, CA, USA) was applied to sections for $15 \mathrm{~min}$. Sections were washed in $3 \times 5$ min PBS and Diaminobenzidine (DAB, Invitrogen, Carlsbad, lot: HD36221, Thermo Fischer, Fremont, CA, USA) were applied to sections up to $10 \mathrm{~min}$. Slides showing reaction was stopped in PBS. Counter staining was done with Harris's Haematoxylin for $45 \mathrm{sec}$, dehydrated through ascending alcohol and cleared in xylene. Product Number: HHS32 SIGMA, Hematoxylin Solution, Harris Modified, Sigma-Aldrich, 3050 Spruce Street, Saint Louis, MO 63103, USA. Slides were mounted with Entellan ${ }^{\circledR}$ (lot: 107961, Sigma-Aldrich, St. Louis, MO, United States) and examined under Olympus BH-2 light microscopy.

\section{Western Blotting}

Cell lysis and protein quantification. The snap frozen cerebellum was grinded to a fine powder in a chilled mortar in the presence of liquid nitrogen. Immediately after grinding, $50 \mathrm{mg}$ cerebellum powder was transferred into a microcentrifuge tube containing $250 \mu$ RIPA lysis buffer (150 mM NaCl, $50 \mathrm{mM}$ Tris, $1 \mathrm{mM}$ EDTA, $1 \%$ (v/v) Triton $\mathrm{X}-100,1 \%(\mathrm{w} / \mathrm{v})$ sodium deoxycholate, $0.1 \%(\mathrm{w} / \mathrm{v})$ SDS, $0.2 \%(\mathrm{w} / \mathrm{v})$ sodium fluoride, $0.2 \%(\mathrm{w} / \mathrm{v})$ sodium orthovanadate and $1 ¥$ protease inhibitor mixture (CompleteTM EDTA free; Roche Diagnostics) and incubated in ice for $1 \mathrm{~h}$. After incubation, aliquots were snap-frozen in liquid nitrogen and stored $-86^{\circ} \mathrm{C}$. All these steps were performed on ice to minimize protein degradation. Total cellular protein concentration was determined in triplicate using a BCA protein assay according to manufacturer's instructions (Pierce, Thermo scientific). The BCA assay was performed in a 96-well plate using MultiscanTM GO microplate from Thermo Scientific.

SDS-PAGE. All protein samples were resolved by $10 \%$ (v/ v) polyacrylamide gel using a Mini Protean Tetra Cell apparatus system (Bio-Rad). The protein samples were prepared in $1 ¥$ SDS loading buffer $(2 \%$ (w/v) SDS, $5 \%$ (v/ v) glycerol, $0.01 \%(\mathrm{w} / \mathrm{v})$ bromophenol blue, $8 \%(\mathrm{w} / \mathrm{v}) \mathrm{DTT}$, which was added just before heating) and heated at $95{ }^{\circ} \mathrm{C}$ for $5 \mathrm{~min}$. The protein samples $(20 \mu \mathrm{g})$ were then loaded on to the $10 \%(\mathrm{v} / \mathrm{v})$ polyacrylamide gel and electrophoresed at $200 \mathrm{~V}$ for $1 \mathrm{~h}$ in a SDS running buffer (2.4 mM Tris, 19.2 $\mathrm{mM}$ glycine, $0.01 \%$ (w/v) SDS). 
Membrane transfer and antibody staining. Separated proteins from the SDS-PAGE were transferred onto the PVDF membrane at $100 \mathrm{~V}$ for $1 \mathrm{~h}$ in transfer buffer $(25 \mathrm{mM}$ Tris, $192 \mathrm{mM}$ glycine, $20 \%$ (v/v) methanol, $\mathrm{pH}$ 8.3) using a Criterion Blotter Transfer System (Bio Rad). The membrane was then blocked with $5 \%(\mathrm{w} / \mathrm{v})$ skim milk powder in PBS$\mathrm{T}(\mathrm{PBS}+0.1 \%(\mathrm{v} / \mathrm{v})$ Tween-20) for $1 \mathrm{~h}$ at room temperature. After blocking, the membrane was probed with primary antibodies in 1: 1000 dilution (anti-Bcl-2, anti-VEGF and anti-CD68 obtained from Santa Cruz Biotechnology for $2 \mathrm{~h}$ at room temperature. The membrane was then washed four times over 30 min with PBS-T before probing with horseradish peroxidase-conjugated secondary antibodies in 1:10000 dilutions for $1 \mathrm{~h}$ at room temperature. The membrane was again washed four times over $30 \mathrm{~min}$ with PBS-T. The protein bands were visualized using ECL (Bio-Rad) according to manufacturer's instruction. The images were taken using ChemiDocTM MP (Bio-Rad).

Statistical analysis. Data analysis was performed using SPSS for windows, version 18 (SPSS, Inc., Chicago, IL, USA). All data were presented as mean \pm standard deviation (SD). Groups of data were compared with an analysis of variance (ANOVA) followed by Tukey's multiple comparison tests. Values of $\mathrm{p}<0.05$ were considered as significant.

\section{RESULTS}

In our study, control, trauma and trauma+Ganoderma lucidum groups were compared in terms of biochemical datas. MPO activity, which is accepted as an indicator of neutrophil infiltration, was significantly higher in the cereballar tissues of traumatic rats than those of the control group $(\mathrm{p}<0.001)$. Ganoderma lucidum treatment significantly decreased cerebellar tissue MPO levels $(\mathrm{p}<0.001)$. Trauma caused a significant increase in the MDA levels ( $\mathrm{p}<0.001)$ with a concomitant decrease in GSH levels $(\mathrm{p}<0.001)$. Ganoderma lucidum treatment significantly reduced the increase in MDA levels and restored GSH content at day 7. Figs. 1-3

Tissue EB content was significantly higher in the cereballar tissues of traumatic rats than those of the control group ( $\mathrm{p}<0.001)$. Ganoderma lucidum treatment significantly decreased cerebellar tissue EB content $(p<0.001)$. And, brain water content, which is accepted as an indicator of edema, was significantly higher in the cereballar tissues of traumatic rats than those of the control group $(\mathrm{p}<0.001)$. Results of biochemical analysis were shown in Table I.
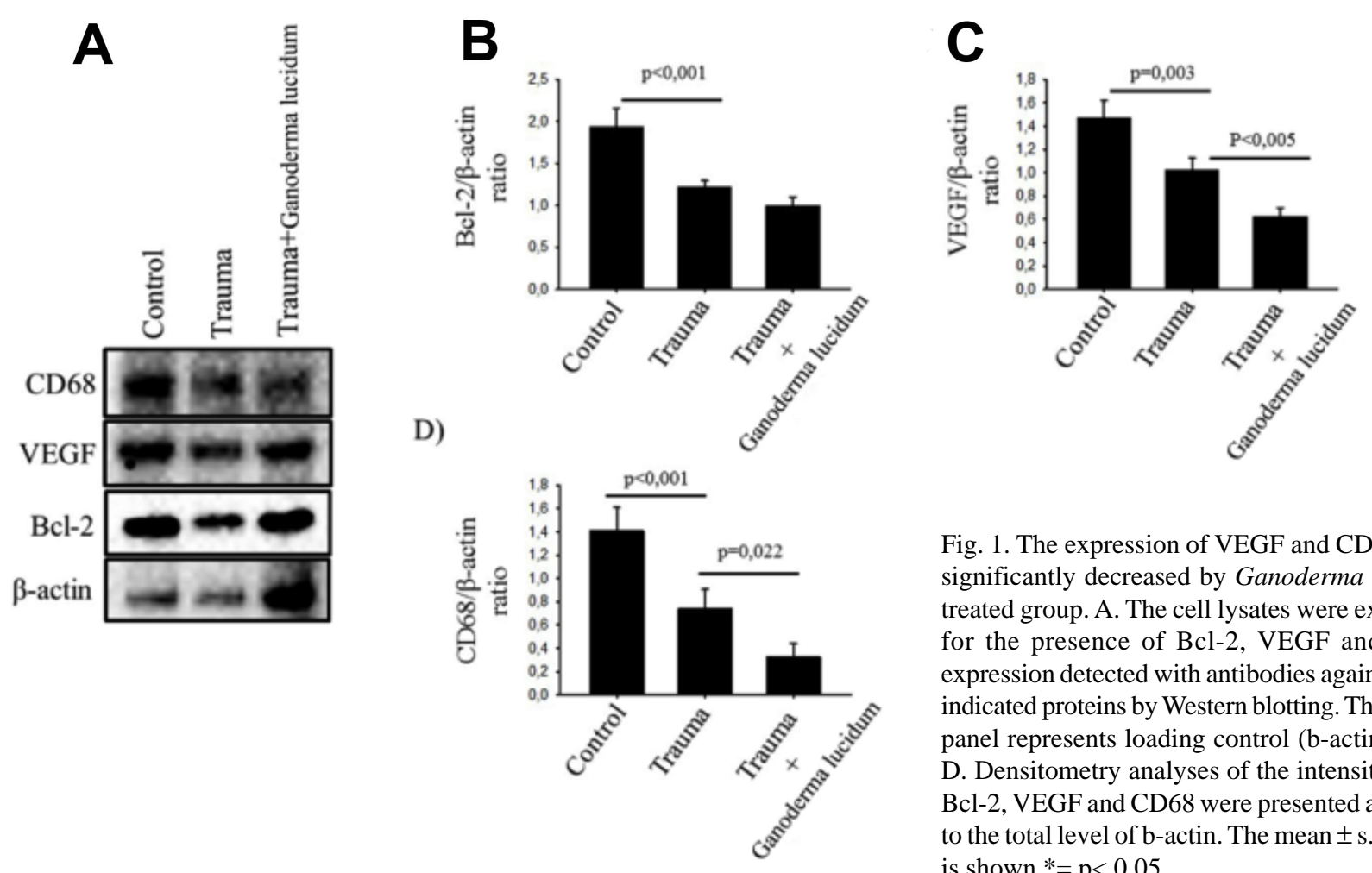

Fig. 1. The expression of VEGF and CD68 were significantly decreased by Ganoderma lucidum treated group. A. The cell lysates were examined for the presence of Bcl-2, VEGF and CD68 expression detected with antibodies against to the indicated proteins by Western blotting. The lowest panel represents loading control (b-actin). B-CD. Densitometry analyses of the intensity of the $\mathrm{Bcl}-2$, VEGF and CD68 were presented as a ratio to the total level of $b$-actin. The mean \pm s.d. $(n=3)$ is shown. ${ }^{*}=\mathrm{p}<0.05$. 

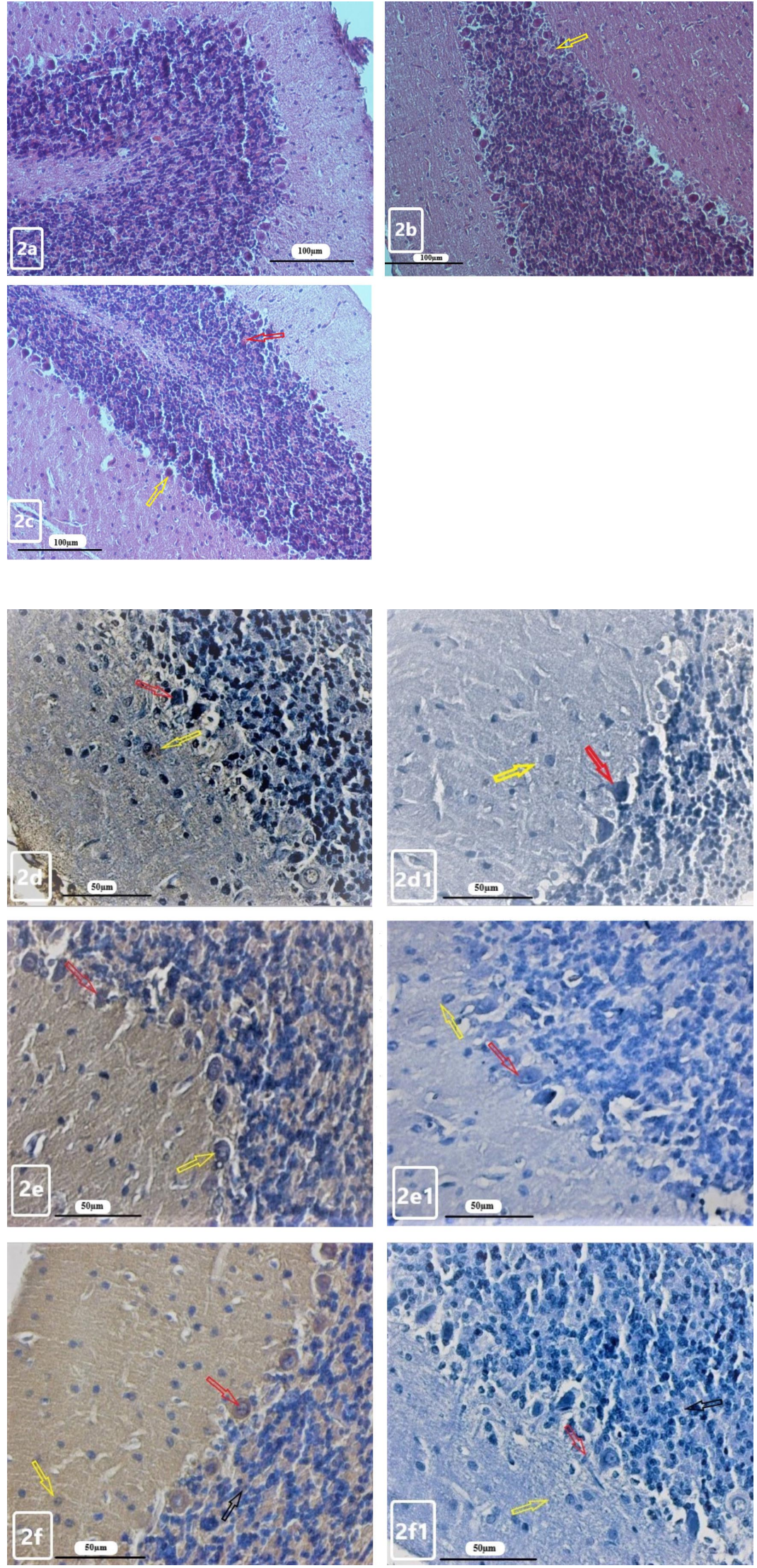

Fig. 2a-Control group. Normal appearance of the cerebellar tissue, H\&E staining Bar $100 \mu \mathrm{m}, 2 \mathrm{~b}$-Trauma group. Degeneration and vacularisation in some purkinje cells in the ganglion layer (yellow arrow) and hemorrhagie in small capillary vessels (red arrow), H\&E staining, Bar $100 \mu \mathrm{m}, 2 \mathrm{c}-$ Trauma+G.lucidum group. Small vacuolization and poor degeneration in purkinje cells (yellow arrow) was regularly seen towards the molecular layer of the extensions in the periphery. Weak hemorrhage in small veins in the granular layer (red arrow), the stratum granular and glial cells were observed as oval-shaped, H\&E staining Bar $100 \mu \mathrm{m}$.

Fig. 2d-Control group. Weak CD68 expression in glia (yellow arrow) and Purkinje cells (red arrow) in the substantia grisea and substantia alba layer, CD68 immunostaining Bar $50 \mu \mathrm{m}, 2 \mathrm{~d} 1$-Control group. CD68 immunostaining negative slides, Bar $50 \mu \mathrm{m}, 2 \mathrm{e}$-Trauma group. Positive CD68 expression in glia (yellow arrow) and Purkinje cells (red arrow), CD68 immun-staining Bar $50 \mu \mathrm{m}, 2 \mathrm{e} 1$ Trauma group. CD68 immunostaining negative slides, Bar $50 \mu \mathrm{m}, 2 \mathrm{f}-$ Trauma+G.lucidum group. Weak CD68 expression in glia cells (yellow arrow), Purkinje cells (red arrow), and granular cells (black arrow), CD68 immun-staining Bar $50 \mu \mathrm{m}$, 2f1-Trauma+G.lucidum group. CD68 immunostaining negative slides, Bar $50 \mu \mathrm{m}$. 

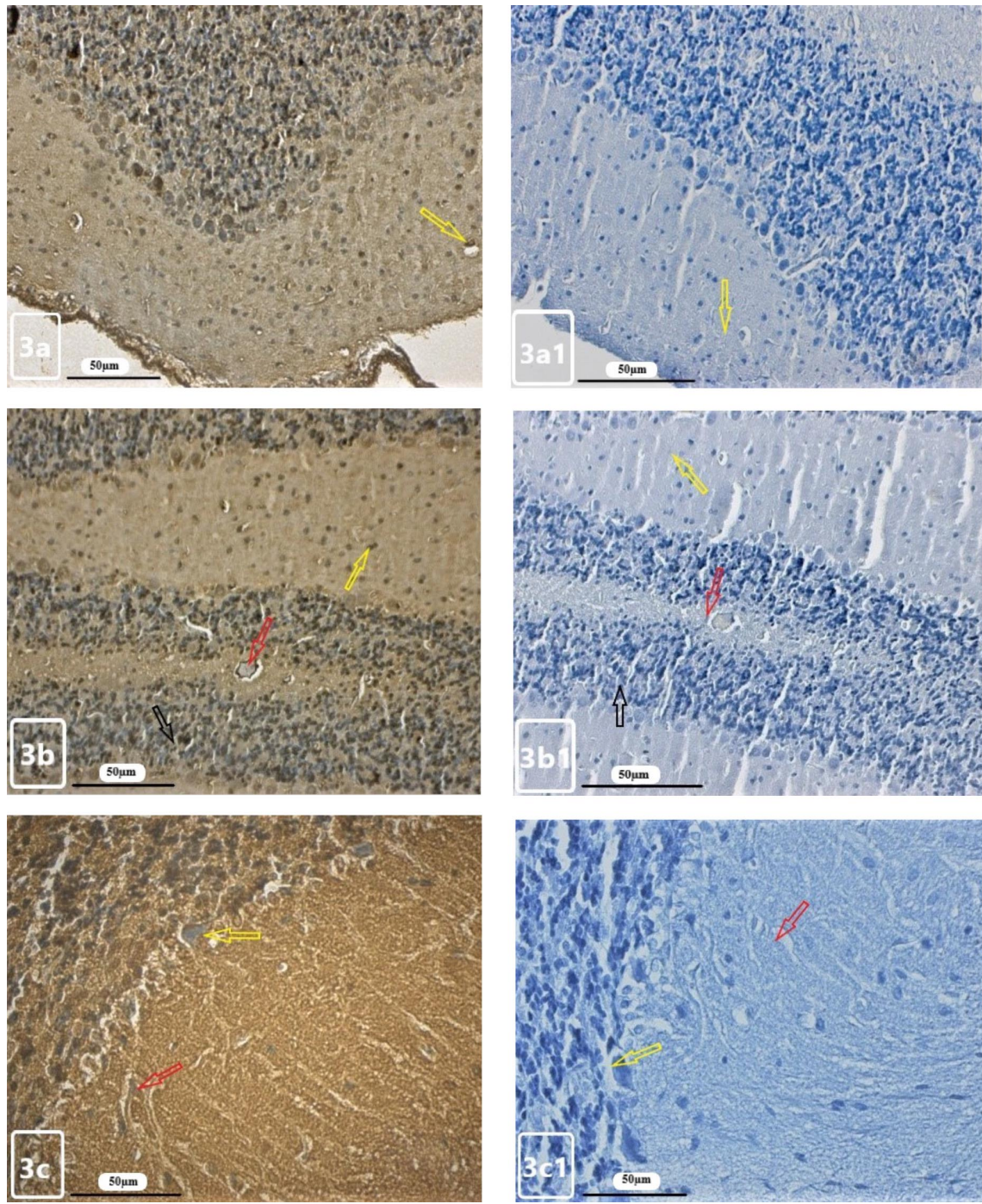

Fig. 3a-Control group. Positive VEGF expression in capillary vascular endothelial cells (yellow arrow), VEGF immunstaining Bar $50 \mu \mathrm{m}$, 3a1-Control group. VEGF immunostaining negative slides, Bar $50 \mu \mathrm{m}$, 3b-Trauma group. Positive VEGF expression in the glomerular areas (black arrow), glial (yellow arrow) and endothelial cells (red arrow) in the molecular layer, VEGF immunostaining Bar $50 \mu \mathrm{m}$, 3b1-Trauma group. VEGF immunostaining negative slides, Bar 50 $\mu \mathrm{m}, 3 \mathrm{c}$-Trauma+G.lucidum group. Positive VEGF expression in small blood vessels (red arrow), and weak VEGF expression in purkinje cells (yellow arrow), VEGF immunostaining Bar $50 \mu \mathrm{m}, 3 \mathrm{c} 1$ Trauma+G.lucidum group. VEGF immunostaining negative slides, Bar 50 $\mu \mathrm{m}, 3 \mathrm{~d}$-Control group. Negative Bcl-2 expression in Purkinje (red arrow) and glial cells (yellow arrow), Bcl-2 immunostaining Bar $50 \mu \mathrm{m}, 3 \mathrm{~d} 1-$ Control group. Bcl-2 immunostaining negative slides, Bar $50 \mu \mathrm{m}, 3 \mathrm{e}$-Trauma group. Positive Bcl-2 expression in Purkinje cells (red arrow) and glomerular area (yellow arrow), Bcl-2 immunostaining Bar $50 \mu \mathrm{m}$, 3e1-Trauma group. Bcl-2 immunostaining negative slides, Bar $50 \mu \mathrm{m}$, 3fTrauma+G.lucidum group. Reduction of $\mathrm{Bcl} 2$ expression intensities in some purkinje (red arrow) and granular cells (yellow arrow), Bcl-2 immunostaining Bar $50 \mu \mathrm{m}, 3 \mathrm{f} 1$-Trauma+G.lucidum group. Bcl-2 immunostaining negative slides, Bar $50 \mu \mathrm{m}$.

Table I. Biochemical results relevant to the study groups.

\begin{tabular}{lccc} 
& Control & Trauma & Trauma+ G. lucidum \\
\hline MDA $(\mathrm{nmol} / \mathrm{g})$ & $36.74 \pm 1.08$ & $56.83 \pm 1.67 * * *$ & $49.1 \pm 1.36^{+++; * * *}$ \\
GSH $(\mu \mathrm{mol} / \mathrm{g})$ & $1.13 \pm 0.1$ & $0.76 \pm 0.13^{* * *}$ & $1.04 \pm 0.09^{+++, * *}$ \\
MPO $(\mathrm{U} / \mathrm{g})$ & $5.55 \pm 0.67$ & $8.26 \pm 0.7 * * *$ & $6.09 \pm 0.49^{+++, *}$ \\
Brain Water Content $(\%)$ & $81.37 \pm 1.28$ & $88.51 \pm 1.4 * * *$ & $83.08 \pm 0.97^{+++} * * *$ \\
Blood-Brain Barrier Permeability $(\mathrm{mg} / \mathrm{g})$ & $6.17 \pm 0.79$ & $9.18 \pm 0.72 * * *$ & $6.57 \pm 0.52^{+++}$
\end{tabular}

Values are represented as mean \pm SD. Each group consists of twelve rats. MDA (Malondialdehyde), GSH (Glutathione), MPO (Myeloperoxidase), $* * * \mathrm{p}<0.001$, versus control, ${ }^{* *} \mathrm{p}<0.01$, versus control ${ }^{*} \mathrm{p}<0.05$, versus control ,+++p $<0.001$, versus trauma ,$++p<0.01$, versus trauma

$+\mathrm{p}<0.05$, versus trauma

\section{DISCUSSION}

Ganoderma lucidum polysaccharides also has long been used as a traditional medicine for revival and a long life, whose hyphal body or the constituents is reported to have various physiological activities including antihyperglycemic (Zhang \& Lin, 2004) immunomodulating (Zhu \& Lin, 2005), antineoplastic (Gao et al., 2005), antiviral 
ÖZEVREN, H.; IRTEGÜN, S.; EKINGEN, A.; TUNCER, M. C.; GÖKALP ÖZKORKMAZ, E.; DEVECI, E. \& DEVECI, S. Immunoexpressions of Vascular endothelial growth factor, $\beta$-cell lymphoma 2 and Cluster of Differentiation 68 in cerebellar tissue of rats treated with Ganoderma lucidum. Int. J. Morphol., 36(4) :1453-1462, 2018.

(Liu et al., 2004), cholesterol-lowering (Hajjaj et al., 2005), and antioxidative effects (Wong et al., 2004). As G. lucidum also contains solid medium-degradation products, including water-soluble lignin caused by the hyphal bodies and hyphal autodigestion in addition to hyphal body components, its activity may differ from that of Reishi mushroom. The activities that have been reported include antihyperglycemic (Usui et al., 2007; Kamiuchi et al., 2010; Kawahara et al., 2011; Kamiuchi et al., 2014), immunostimulating (Nakagawa et al., 1999), antineoplastic (Lu et al., 2003), antidepressive-like (Matsuzaki et al., 2013), and antihypertensive effects (Fukaya et al., 2015).

Polysaccharides, isolated from G. lucidum fruiting bodies, have antioxidant (Liu et al.) immunomodulatory (Bao et al., 2001) and antitumor properties (Cao \& Lin, 2006). Moreover, polysaccharides were protective against cerebral ischemic injury (Zhou et al., 2010) and traumatic spinal cord injury in rats (Gokce et al., 2015). GLPS induced neuronal differentiation of pheochromocytoma cell cultures and protected PC12 neurons from apoptosis, by the Erk1/2 and the CREB signaling pathways. And, they reported that Ganoderma lucidum contains neuroactive compounds that can induce neural differentiation and prevent apoptosis of NGF-dependent neurons (Transforming growth factor) (Cheung et al.). G. lucidum extracts decreased inflammatory mediator production by activated microglia and protected dopaminergic neurons against inflammatory and oxidative damage (Zhang et al., 2011). Furthermore, G. lucidum spores preserved injured spinal motor neurons by modulating expression of proteins important for axonal regeneration (Zhang et al., 2006). These findings suggested that polysaccharides isolated from $G$. lucidum had both neuroprotective and antioxidant properties. Moreover, Sun et al. (2017) reported on the neuroprotective effects of GLPS against oxidative stress-induced apoptosis in cultured cerebellar granule cells.

G. lucidum extract reduced the expressions of proinflammatory and cytotoxic factors from the activated microglia, and effectively protected the dopaminergic neurons against inflammatory and oxidative damage (Huang et al., 2012). After trauma, increased protein expression of VEGF causes increased blood vessel permeability.

Ganoderma lucidum administered post-traumatized VEGF is thought to help reduce the concentration of VEGF and reduce vascular permeability. Strong microglial activation is a common inflammatory response observed following injury to the cerebellum. Following either fluid percussion injury or controlled-cortical impact, activated microglia are organized perpendicular to the Purkinje cell layer (Fukuda et al., 1996; Mautes et al., 1996). After traumatic brain injury, Activated microglia Purkinje cell damage is reported to be a sensitive indicator and may act as a cell cleaner to remove debris and promote wound healing (Kim \& de Vellis, 2005). CD68 expression,especially in the glomerular area of the granular layer, increased in the microglia cells after trimming. In accordance with this, there was an increase in VEGF expression in endothelial cells and inflammatory cells in enlarged blood vessels.

The amount of apoptosis necessary for physiological brain development is determined by the degree of myelinization and the water content of the brain (Smith et al., 1995). It has been suggested that apoptosis of oligodendrocytes after traumatic CNS injury may be a result of either the direct trauma or a secondary event due to loss of trophic support from the degenerating axons (Beattie et al., 1998). Aqueous extract of Ganoderma lucidum significantly attenuated Ab-induced synaptotoxicity and apoptosis by preserving the synaptic density protein called synaptophysin (Lai et al.). Further, a study by Wang et al. (2004) concluded that senescence-accelerated mice (strain SAMP8) given a diet supplemented with Ganoderma extract exhibited significantly lower brain amyloid and higher antioxidation activities such as superoxide dismutase, glutathione peroxidase (GPx), and glutathione reductase when compared with the control mice.

\section{CONCLUSION}

Ganoderma lucidum polysaccharides have protective effects against apoptosis and inflamations in neurons exposed to traumatic brain injury in rats. Ganoderma lucidum is thought to induce angiogenetic development in cerebellar tissue after traumatic brain injury, reducing inflammation and apoptotic changes in nerves and glial cells. Small vacuolization and poor degeneration in Purkinje cells was regularly seen towards the molecular layer of the extensions in the periphery. Weak hemorrhages in small veins were seen in the granular layer. The stratum granular cells and glial cells were observed as oval-shaped. Positive VEGF expression was seen in the glomerular areas, glial and endothelial cells in the trauma group, which suggest that VEGF may be derived from astrocytes and neurons. In addition, we determined that weak VEGF expression was seen in purkinje cells, weak CD68 expression was seeen in microglia, Purkinje and granular cells, and reduction of $\mathrm{Bcl} 2$ expression intensities was seen in Purkinje and granular cells in the treated Ganoderma lucidum group. These histopathological findings suggested that Ganoderma lucidum polysaccharides may play a certain role for expression of apoptosis-associated proteins and have 
significant neuroprotective effects. Although apoptosis ascribed to oxidative stress and inflammatory processes is believed to play a major role, Ganoderma lucidum polysaccharides has been shown to suppress necrosis, protect neural structures, as well as neuronal apoptosis, indicating that further studies are needed concerning the mechanism of activity because the cereballar-protective effect of Ganoderma lucidum polysaccharides cannot be solely explained by histopathological findings.

ÖZEVREN, H.; IRTEGÜN, S.; EKINGEN, A.; TUNCER, M. C.; GÖKALP ÖZKORKMAZ, E.; DEVECI, E. \& DEVECI, S. Inmunoexpresión del factor de crecimiento endotelial vascular, linfoma de células $\beta 2$ y grupo de diferenciación 68 en tejido cerebeloso de ratas tratadas con Ganoderma lucidum. Int. J. Morphol., 36(4):1453-1462, 2018.

RESUMEN: La lesión cerebral traumática (LCT) puede provocar hemorragias en todas las áreas del cráneo, lo que puede dañar las células y las conexiones nerviosas. Este estudio tuvo como objetivo investigar los efectos protectores de los polisacáridos de Ganoderma lucidum (GLPS) como antioxidante en los tejidos de las células del cerebelo después de la lesión cerebral traumática en ratas. Ratas Sprague Dawley fueron sometidas a TBI con un dispositivo de caída de peso usando un impacto de peso de $300 \mathrm{~g}-1 \mathrm{~m}$. Se formaron los siguientes grupos: control, trauma y trauma + Ganoderma lucidum. Siete días después de la lesión cerebral, las ratas experimentales fueron decapitadas después de la administración intraperitoneal de ketamina $\operatorname{HCL}(0,15$ $\mathrm{ml} / 100 \mathrm{~g}$ de peso corporal). Se tomaron muestras cerebrales para el examen histológico y para la determinación de niveles de malondialdehído (MDA) y glutatión (GSH) y actividad de mieloperoxidasa (MPO). Se observó una mejora significativa en las células y las estructuras vasculares de los grupos tratados con Ganoderma lucidum en comparación con los grupos no tratados. Durante el estudio se observó que Ganoderma lucidum puede tener un efecto sobre la progresión de la lesión cerebral traumática. La aplicación de Ganoderma lucidum puede afectar el desarrollo angiogénico en las células endoteliales de los vasos sanguíneos, disminuir la acumulación de células inflamatorias al afectar el mecanismo de las citocinas y puede crear células nerviosas apoptóticas y un mecanismo neuroprotector en las células gliales.

PALABRAS CLAVE: VEGF; Bcl-2; CD68, Ganoderma lucidum; Lesión cerebral traumática; Cerebelo; Histopatología; Rata.

\section{REFERENCES}

Allsopp, T. E.; Wyatt, S.; Paterson, H. F. \& Davies, A. M. The protooncogene bcl-2 can selectively rescue neurotrophic factor-dependent neurons from apoptosis. Cell, 73(2):295-307, 1993.

Andjelkovic, A. V.; Nikolic, B.; Pachter, J. S. \& Zecevic, N. Macrophages/ microglial cells in human central nervous system during development: an immunohistochemical study. Brain Res., 814(1-2):13-25, 1998.
Bao, X.; Liu, C.; Fang, J. \& Li, X. Structural and immunological studies of a major polysaccharide from spores of Ganoderma lucidum (Fr.) Karst. Carbohydr. Res., 332(1):67-74, 2001.

Barrientos, R. M.; Higgins, E. A.; Biedenkapp, J. C.; Sprunger, D. B.; Wright-Hardesty, K. J.; Watkins, L. R.; Rudy, J. W. \& Maier, S. F. Peripheral infection and aging interact to impair hippocampal memory consolidation. Neurobiol. Aging, 27(5):723-32, 2006.

Batistatou, A.; Merry, D. E.; Korsmeyer, S. J. \& Greene, L. A. Bcl-2 affects survival but not neuronal differentiation of PC12 cells. J. Neurosci., 13(10):4422-8, 1993

Beattie, M. S.; Shuman, S. L. \& Bresnahan, J. C. Review : Apoptosis and spinal cord injury. Neuroscientist, 4:163-71, 1998.

Cao, Q. Z. \& Lin, Z. B. Ganoderma lucidum polysaccharides peptide inhibits the growth of vascular endothelial cell and the induction of VEGF in human lung cancer cell. Life Sci., 78(13):1457-63, 2006.

Chen, J.; Buchanan, J. B.; Sparkman, N. L.; Godbout, J. P.; Freund, G. G. \& Johnson, R. W. Neuroinflammation and disruption in working memory in aged mice after acute stimulation of the peripheral innate immune system. Brain Behav. Immun., 22(3):301-11, 2008.

Chen, J.; Flannery, J. G.; LaVail, M. M.; Steinberg, R. H.; Xu, J. \& Simon, M. I. bcl-2 overexpression reduces apoptotic photoreceptor cell death in three different retinal degenerations. Proc. Natl. Acad. Sci. U. S. A., 93(14):7042-7, 1996.

Cheung, W. M.; Hui, W. S.; Chu, P. W.; Chiu, S. W. \& Ip, N. Y. Ganoderma extract activates MAP kinases and induces the neuronal differentiation of rat pheochromocytoma PC12 cells. F. E. B. S. Lett., 486(3):291-6, 2000

Clark, R. S.; Chen, J.; Watkins, S. C.; Kochanek, P. M.; Chen, M.; Stetler, R. A.; Loeffert, J. E. \& Graham, S. H. Apoptosis-suppressor gene bcl-2 expression after traumatic brain injury in rats. J. Neurosci., 17(23):917282, 1997.

Cong, Z. \& Lin, Z. B. The pharmacological study of Lingzhi (Ganoderma lucidum) and the research of therapeutical principle of "Fuzhengguben" in Traditional Chinese medicine. J. Beijing Med. Coll., 13:6-10, 1981.

Connor, B. \& Dragunow, M. The role of neuronal growth factors in neurodegenerative disorders of the human brain. Brain Res. Rev., 27(1):139, 1998.

D'Ambrosi, N.; Cavaliere, F.; Merlo, D.; Milazzo, L.; Mercanti, D. \& Volonté, C. Antagonists of $\mathrm{P} 2$ receptor prevent NGF-dependent neuritogenesis in PC12 cells. Neuropharmacology, 39(6):1083-94, 2000.

de Bilbao, F. \& Dubois-Dauphin, M. Time course of axotomy-induced apoptotic cell death in facial motoneurons of neonatal wild type and bcl2 transgenic mice. Neuroscience, 71(4):1111-9, 1996.

Dubois-Dauphin, M.; Frankowski, H.; Tsujimoto, Y.; Huarte, J. \& Martinou, J. C. Neonatal motoneurons overexpressing the bcl-2 protooncogene in transgenic mice are protected from axotomy-induced cell death. Proc. Natl. Acad. Sci. U. S. A., 91(8):3309-13, 1994.

Farlie, P. G.; Dringen, R.; Rees, S. M.; Kannourakis, G. \& Bernard, O. bcl-2 transgene expression can protect neurons against developmental and induced cell death. Proc. Natl. Acad. Sci. U. S. A., 92(10):4397-401, 1995.

Fukaya, M.; Iwata, N.; Shouji, S.; Kamiuchi, S.; Okazaki, M.; Asano, S.; Miyano, Y.; Iizuka, H. \& Hibino, Y. Antihypertensive effect of a watersoluble extract from culture medium of Ganoderma lucidum mycelia (MAK) in spontaneously hypertensive rats. New Food Ind., 57:1-11, 2015.

Fukuda, K.; Aihara, N.; Sagar, S. M.; Sharp, F. R.; Pitts, L. H.; Honkaniemi, J. \& Noble, L. J. Purkinje cell vulnerability to mild traumatic brain injury. J. Neurotrauma, 13(5):255-66, 1996.

Gao, Y.; Gao, H.; Chan, E.; Tang, W.; Xu, A.; Yang, H.; Huang, M.; Lan, J.; Li, X.; Duan, W.; Xu, C. \& Zhou, S. Antitumor activity and underlying mechanisms of ganopoly, the refined polysaccharides extracted from Ganoderma lucidum, in mice. Immunol. Invest., 34(2):171-98, 2005.

Garcia, I.; Martinou, I.; Tsujimoto, Y. \& Martinou, J. C. Prevention of programmed cell death of sympathetic neurons by the bcl-2 protooncogene. Science, 258(5080):302-4, 1992. 
Gokce, E. C.; Kahveci, R.; Atanur, O. M.; Gürer, B.; Aksoy, N.; Gokce, A.; Sargon, M. F.; Cemil, B.; Erdogan, B. \& Kahveci, O. Neuroprotective effects of Ganoderma lucidum polysaccharides against traumatic spinal cord injury in rats. Injury, 46(11):2146-55, 2015.

Granholm, A. C.; Albeck, D.; Bäckman, C.; Curtis, M.; Ebendal, T.; Friden, P.; Henry, M.; Hoffer, B.; Kordower, J.; Rose, G. M.; Söderström, S. \& Bartus, R. T. A non-invasive system for delivering neural growth factors across the blood-brain barrier: a review. Rev. Neurosci., 9(1):31-55, 1998.

Gumerlock, M. K. Blood-Brain Barrier and Cerebral Edema. In: Tindall, G. T.; Cooper, P. R. \& Barrow, D. L. (Eds.). The Practice of Neurosurgery. Baltimore, Williams \& Wilkins, 1996. pp.4-12.

Haigh, J. J.; Morelli, P. I.; Gerhardt, H.; Haigh, K.; Tsien, J.; Damert, A.; Miquerol, L.; Muhlner, U.; Klein, R.; Ferrara, N.; Wagner, E. F.; Betsholtz, C. \& Nagy, A. Cortical and retinal defects caused by dosagedependent reductions in VEGF-A paracrine signaling. Dev. Biol., 262(2):225-41, 2003.

Hajjaj, H.; Macé, C.; Roberts, M.; Niederberger, P. \& Fay, L. B. Effect of 26-oxygenosterols from Ganoderma lucidum and their activity as cholesterol synthesis inhibitors. Appl. Environ. Microbiol., 71(7):3653$8,2005$.

Hakan, T.; Toklu, H. Z.; Biber, N.; Ozevren, H.; Solakoglu, S.; Demirturk, P. \& Aker, F. V. Effect of COX-2 inhibitor meloxicam against traumatic brain injury-induced biochemical, histopathological changes and bloodbrain barrier permeability. Neurol. Res., 32(6):629-35, 2010.

Harhaji Trajkovic, L. M.; Mijatovic, S. A.; Maksimovic-Ivanic, D. D.; Stojanovic, I. D.; Momcilovic, M. B.; Tufegdzic, S. J.; Maksimovic, V. M.; Marjanovic, Z. S. \& Stosic-Grujicic, S. D. Anticancer properties of Ganoderma lucidum methanol extracts in vitro and in vivo. Nutr. Cancer, 61(5):696-707, 2009.

Hefti, F. \& Weiner, W. J. Nerve growth factor and Alzheimer's disease. Ann. Neurol., 20(3):275-81, 1986.

Henry, C. J.; Huang, Y.; Wynne, A. M. \& Godbout, J. P. Peripheral lipopolysaccharide (LPS) challenge promotes microglial hyperactivity in aged mice that is associated with exaggerated induction of both proinflammatory IL-1beta and anti-inflammatory IL-10 cytokines. Brain Behav. Immun., 23(3):309-17, 2009.

Hillegass, L. M.; Griswold, D. E.; Brickson, B. \& Albrightson-Winslow, C. Assessment of myeloperoxidase activity in whole rat kidney. $J$. Pharmacol. Methods, 24(4):285-95, 1990.

Huang, C. Y.; Chen, J. Y.; Wu, J. E.; Pu, Y. S.; Liu, G. Y.; Pan, M. H.; Huang, Y. T.; Huang, A. M.; Hwang, C. C.; Chung, S. J. \& Hour, T. C. Ling-Zhi polysaccharides potentiate cytotoxic effects of anticancer drugs against drug-resistant urothelial carcinoma cells. J. Agric. Food Chem., 58(15):8798-805, 2010.

Huang, T. T.; Zou, Y. \& Corniola, R. Oxidative stress and adult neurogenesis-effects of radiation and superoxide dismutase deficiency. Semin. Cell. Dev. Biol., 23(7):738-44, 2012.

Kamiuchi, S.; Hatta, Y.; Miyazato, A.; Okazaki, M.; Kawahara, Y.; Tanaka, A.; Shindou, Y.; Xuan, M.; Suzuki, F.; Iizuka, H. \& Hibino, Y. Hypoglycemic effects of a water-soluble extract from culture medium of Ganoderma lucidum (Rei-shi) mycelia in type 2 diabetic mice. Jpn. J. Complement. Altern. Med., 7(1):35-42, 2010.

Kamiuchi, S.; Shindo, Y.; Utsumi, Y.; Iwata, N.; Okazaki, M.; Suzuki, F.; Iizuka, H.; Asano, S.; Matsuzaki, H. \& Hibino, Y. Influence of a watersoluble extract from culture medium of Ganoderma lucidum mycelia (WER) on carbohydrate metabolism in the liver of type 2 diabetic mice. Jpn. J. Complement. Altern. Med., 11(1):57-66, 2014.

Kawahara, Y.; Kamiuchi, S.; Okazaki, M.; Iwata, N.; Usui, T.; Xuan, M.; Suzuki, F.; Iizuka, H. \& Hibino, Y. Inhibitory Effects of a water-soluble extract from culture medium of Ganoderma lucidum (Rei-shi) mycelia on postprandial blood glucose elevation in type 2 diabetic mice and additional effect with a-glucosidase inhibitors. Jpn. J. Complement. Altern. Med., 8(1):1-9, 2011

Kim, S. U. \& de Vellis, J. Microglia in health and disease. J. Neurosci. Res., 81(3):302-13, 2005.
Lai, C. S.; Yu, M. S.; Yuen, W. H.; So, K. F.; Zee, S. Y. \& Chang, R. C. Antagonizing beta-amyloid peptide neurotoxicity of the anti-aging fungus Ganoderma lucidum. Brain Res., 1190:215-24, 2008.

Liu, J.; Yang, F.; Ye, L. B.; Yang, X. J.; Timani, K. A.; Zheng, Y. \& Wang, Y. H. Possible mode of action of antiherpetic activities of a proteoglycan isolated from the mycelia of Ganoderma lucidum in vitro. $J$. Ethnopharmacol., 95(2-3):265-72, 2004.

Lu, H.; Kyo, E.; Uesaka, T.; Katoh, O. \& Watanabe, H. A water-soluble extract from cultured medium of Ganoderma lucidum (Rei-shi) mycelia suppresses azoxymethane-induction of colon cancers in male F344 rats. Oncol. Rep., 10(2):375-9, 2003.

Marmarou, A.; Foda, M. A.; van den Brink, W.; Campbell, J.; Kita, H. \& Demetriadou, K. A new model of diffuse brain injury in rats. Part I: Pathophysiology and biomechanics. J. Neurosurg., 80(2):291-300, 1994.

Matsuzaki, H.; Shimizu, Y.; Iwata, N.; Kamiuchi, S.; Suzuki, F.; Iizuka, H.; Hibino, Y. \& Okazaki, M. Antidepressant-like effects of a watersoluble extract from the culture medium of Ganoderma lucidum mycelia in rats. B. M. C. Complement. Altern. Med., 13:370, 2013.

Mautes, A. E.; Fukuda, K. \& Noble, L. J. Cellular response in the cerebellum after midline traumatic brain injury in the rat. Neurosci. Lett., 214(23):95-8, 1996

Nag, S.; Takahashi, J. L. \& Kilty, D. W. Role of vascular endothelial growth factor in blood-brain barrier breakdown and angiogenesis in brain trauma. J. Neuropathol. Exp. Neurol., 56(8):912-21, 1997.

Nakagawa, I.; Hibino, Y.; Ohashi, Y. \& Sugano, N. Augmentation of cytolytic activity of mouse splenic cells by a heteroglycan-protein fraction from culture medium of Ganoderma lucidum (Rei-shi) mycelia. Biotherapy, 13:513-5, 1999.

Paterson, R. R. Ganoderma - a therapeutic fungal biofactory. Phytochemistry, 67(18):1985-2001, 2006.

Perry, V. H.; Matyszak, M. K. \& Fearn, S. Altered antigen expression of microglia in the aged rodent CNS. Glia, 7(1):60-7, 1993.

Potts, M. B.; Adwanikar, H. \& Noble-Haeusslein, L. J. Models of traumatic cerebellar injury. Cerebellum, 8(3):211-21, 2009.

Preston, G.W. \& Phillips, D.H. Quantification of a peptide standard using the intrinsic fluorescence of tyrosine. Anal. Bioanal. Chem., 408(9):218793, 2016.

Raab, S.; Beck, H.; Gaumann, A.; Yüce, A.; Gerber, H. P.; Plate, K.; Hammes, H. P.; Ferrara, N. \& Breier, G. Impaired brain angiogenesis and neuronal apoptosis induced by conditional homozygous inactivation of vascular endothelial growth factor. Thromb. Haemost., 91(3):595-605, 2004.

Rakic, S. \& Zecevic, N. Early oligodendrocyte progenitor cells in the human fetal telencephalon. Glia, 41(2):117-27, 2003.

Slemmer, J. E.; Weber, J. T. \& De Zeeuw, C. I. Cell death, glial protein alterations and elevated S-100 beta release in cerebellar cell cultures following mechanically induced trauma. Neurobiol. Dis., 15(3):563-72, 2004.

Smith, D. H.; Soares, H. D.; Pierce, J. S.; Perlman, K. G.; Saatman, K. E.; Meaney, D. F.; Dixon, C. E. \& McIntosh, T. K. A model of parasagittal controlled cortical impact in the mouse: cognitive and histopathologic effects. J. Neurotrauma, 12(2):169-78, 1995.

Sohrab, G.; Angoorani, P.; Tohidi, M.; Tabibi, H.; Kimiagar, M. \& Nasrollahzadeh, J. Pomegranate (Punicagranatum) juice decreases lipid peroxidation, but has no effect on plasma advanced glycated endproducts in adults with type 2 diabetes: a randomized double-blind clinical trial. Food Nutr. Res., 59:28551, 2015.

Sun, X. Z.; Liao, Y.; Li, W. \& Guo, L. M. Neuroprotective effects of Ganoderma lucidum polysaccharides against oxidative stress-induced neuronal apoptosis. Neural. Regen. Res., 12(6):953-8, 2017.

Tsai, F. Y.; Teal, J. S.; Itabashi, H. H.; Huprich, J. E.; Hieshima, G. B. \& Segall, H. D. Computed tomography of posterior fossa trauma. $J$. Comput. Assist. Tomogr., 4(3):291-305, 1980.

Ucar, T.; Tanriover, G.; Gurer, I.; Onal, M. Z. \& Kazan, S. Modified experimental mild traumatic brain injury model. J. Trauma., 60(3):558-65, 2006. 
ÖZEVREN, H.; IRTEGÜN, S.; EKINGEN, A.; TUNCER, M. C.; GÖKALP ÖZKORKMAZ, E.; DEVECI, E. \& DEVECI, S. Immunoexpressions of Vascular endothelial growth factor, $\beta$-cell lymphoma 2 and Cluster of Differentiation 68 in cerebellar tissue of rats treated with Ganoderma lucidum. Int. J. Morphol., 36(4) :1453-1462, 2018.

Usui, T.; Okazaki, M.; Kamiuchi, S.; Suzuki, F.; Iizuka, H. \& Hibino, Y. Inhibitory effects of a water-soluble extract from culture medium of Ganoderma lucidum (Rei-shi) mycelia on postprandial blood glucose elevation in mice and additional effect with a-glucosidase inhibitor. $J$. Jpn. Soc. Nutr. Food Sci., 60:249-55, 2007.

Wang, M. F.; Chan, Y. C.; Wu, C. L.; Wong, Y. C.; Hosoda, K. \& Yamamoto, $\mathrm{S}$. Effects of Ganoderma on aging and learning and memory ability in senescence accelerated mice. Int. Congr. Ser., 1260:399-404, 2004

Weng, C. J.; Chau, C. F.; Yen, G. C.; Liao, J. W.; Chen, D. H. \& Chen, K. D. Inhibitory effects of Ganoderma lucidum on tumorigenesis and metastasis of human hepatoma cells in cells and animal models. J. Agric. Food Chem., 57(11):5049-57, 2009.

Wong, K. L.; Chao, H. H.; Chan, P.; Chang, L. P. \& Liu, C. F. Antioxidant activity of Ganoderma lucidum in acute ethanol-induced heart toxicity. Phytother. Res., 18(12):1024-6, 2004.

Wynne, A. M.; Henry, C. J.; Huang, Y.; Cleland, A. \& Godbout, J. P. Protracted downregulation of CX3CR1 on microglia of aged mice after lipopolysaccharide challenge. Brain Behav. Immun., 24(7):1190-201, 2010.

Zhang, H. N. \& Lin, Z. B. Hypoglycemic effect of Ganoderma lucidum polysaccharides. Acta Pharmacol. Sin., 25(2):191-5, 2004.

Zhang, R.; Xu, S.; Cai, Y.; Zhou, M.; Zuo, X. \& Chan, P. Ganoderma lucidum protects dopaminergic neuron degeneration through inhibition of microglial activation. Evid. Based Complement. Alternat. Med., 2011:156810, 2011.

Zhang, W.; Zeng, Y. S.; Wang, Y.; Liu, W.; Cheng, J. J. \& Chen, S. J. Primary study on proteomics about Ganoderma lucidium spores promoting survival and axon regeneration of injured spinal motor neurons in rats. Zhong Xi Yi Jie He Xue Bao, 4(3):298-302, 2006

Zhao, H. B.; Lin, S. Q.; Liu, J. H. \& Lin, Z. B. Polysaccharide extract isolated from Ganoderma lucidum protects rat cerebral cortical neurons from hypoxia/reoxygenation injury. J. Pharmacol. Sci., 95(2):294-8, 2004.

Zhao, H. B.; Wang, S. Z.; He, Q. H.; Yuan, L.; Chen, A. F. \& Lin, Z. B. Ganoderma total sterol (GS) and GS1 protect rat cerebral cortical neurons from hypoxia/reoxygenation injury. Life Sci., 76(9):1027-37, 2005.

Zhou, Y.; Qu, Z. Q.; Zeng, Y. S.; Lin, Y. K.; Li, Y.; Chung, P.; Wong, R. \& Hägg, U. Neuroprotective effect of preadministration with Ganoderma lucidum spore on rat hippocampus. Exp. Toxicol. Pathol., 64(7-8):67380, 2012.

Zhou, Z. Y.; Tang, Y. P.; Xiang, J.; Wua, P.; Jin, H. M.; Wang, Z.; Mori, M. \& Cai, D. F. Neuroprotective effects of water-soluble Ganoderma lucidum polysaccharides on cerebral ischemic injury in rats. $J$. Ethnopharmacol., 131(1):154-64, 2010.

Zhu, X. L. \& Lin, Z. B. Effects of Ganoderma lucidum polysaccharides on proliferation and cytotoxicity of cytokine-induced killer cells. Acta. Pharmacol. Sin., 26(9):1130-7, 2005.

\author{
Corresponding author. \\ M. Cudi Tuncer,Professor, Ph.D. \\ Dicle University \\ Medical School \\ Department of Anatomy, 21280 \\ Diyarbakır \\ TURKEY
}

E-mail: drcudi@hotmail.com

Received: 16-05-2018

Accepted: 06-08-2018 